\title{
Effect of Bulblets Size Oriented from Tissue Culture on Growth and Bulb Enlargement of Lilium Oriental Hybrids Grown in Highlands
}

\author{
Min Jeong Kim, Sae Jin Hong, and Hak Ki Kim* \\ Department of Plant Science, Gangneung-Wonju National University, Gangneung 210-702, Korea
}

\begin{abstract}
This study was conducted to investigate the effect of bulblet size on growth and bulb enlargement of Lilium Oriental hybrids, such as 'Sorbonne', 'Siberia', and 'Casa Blanca', grown in areas of high altitude $(780 \mathrm{~m})$, in 2009. The bulblets were oriented from tissue culture and planted to produce virus-free bulblets. All the three cultivars showed high vitality, with more than $93 \%$ producing shoots, even from small bulblets with a bulb circumference (BC) of less than $6 \mathrm{~cm}$. Bulblets with $\mathrm{BC} 9-10 \mathrm{~cm}$ showed an increased height and number of leaves rapidly to induce the phase conversation from vegetative growth to reproductive growth. The bulblets of BC 9-10 cm in 'Sorbonne', 'Siberia', and 'Casa Blanca' had 2.0, 2.9, and 2.8 flower bud sets per plant, respectively. However, the flowers from those bulblets were not adequate as standard bulbs to produce cut-flowers for the domestic market. The larger bulblets showed more prosperous characteristics in growth and development of Lilium Oriental hybrids. Small bulblets had a high occurrence of viruses and leaf blight symptoms during cultivation, indicating the aggravated disease symptoms in the previously infected bulbs. 'Sorbonne' cultivars showed a high rate of enlargement of bulbs, and small bulblets under BC $6 \mathrm{~cm}$ produced more than $23 \%$ of the standard bulbs of $\mathrm{BC} 14-16 \mathrm{~cm}$, which could produce cut-flowers for export. However, 'Casa Blanca' bulblets with BC 6-9 cm produced low bulbs of BC 14-16 cm at 21\% level. 'Casa Blanca' cultivars had more bulb roots, longer root lengths, and higher weights than 'Sorbonne' and 'Siberia' cultivars. 'Casa Blanca' cultivars with $\mathrm{BC}$ over $9-10 \mathrm{~cm}$ grew rapidly and produced a high quantity of bulbs. In these results, 'Sorbonne' bulblets of BC 9-10, 'Siberia' bulblets of $\mathrm{BC} 10-12 \mathrm{~cm}$, and 'Casa Blanca' bulblets of $\mathrm{BC} 10-12 \mathrm{~cm}$ produced $89 \%, 86 \%$, and $93 \%$ of the standard bulbs of $\mathrm{BC} 14-16 \mathrm{~cm}$, respectively. It is recommended that bulblets larger than the above sizes be used to produce cut-flowers for the export market. Experiment results suggest that production of bulbs larger than $\mathrm{BC} 18 \mathrm{~cm}$ requires bulblets that are larger than $\mathrm{BC} 12-14 \mathrm{~cm}$ of the three cultivars for the highest quality cut-flowers.
\end{abstract}

Additional key words: disease infection, flower bud, seed bulb

\section{Introduction}

Lilies (Lilium longiflorum Thunb.) have attractive flowers and a strong fragrance. Along with roses, chrysanthemums, and carnations, lilies are one of the top four cut-flowers in Korea (Suh and Lee, 1995). The cultivation area for lilies in Korea is 221 ha. $9.7 \%$ of the total cultivated cut-flowers are lilies. Cut-flower lilies are top-ranked in ornamentals export. Their main export country is Japan, where export totals were USD 19.05 million in 2008, USD 24.74 million in 2009, and USD 27.85 million in 2012, showing high growth rates of $29.9 \%$ and $12.6 \%$ compared to previous years (MAF, 2011). However, the import price of bulblets of Lilium is expensive, accounting for $50-70 \%$ of their production cost, so it is necessary to secure superior disease-free bublets in order to improve export competitiveness (Kim, 1999; Kim et al., 1998; Park, 1992). Lilies are a low-temperature crop, so if they are cultivated in the highlands of Daegwanrong (higher than $780 \mathrm{~m}$ ), the cultivation period is shortened compared to the cultivation period of lilies grown in low areas. It is beneficial for seed bulb production to continue bulb growth without inducing dormancy during the hot seasons of July and August in the highlands (Hong et al., 2001; Jeong, 2001; Kim, 1999). The low-temperature, high-humidity climate conditions of the highland are also beneficial for the production of diseasefree bulbs because there is a lower density of aphids, the main insect vectors for viruses, in these conditions (Hong

\footnotetext{
*Corresponding author: hakgikim@gwnu.ac.kr

※ Received 21 November 2012; Revised 14 December 2012; Accepted 20 December 2012. This study was conducted with support from The Korea Institute of Planning and Evaluation for Technology and The Korean Ministry for Food, Agriculture, Forestry and Fisheries.
} 
et al., 2001; Jeong, 2001; Kim et al., 2000). In addition, in highlands, the amount of sunshine and UV radiation is high and the temperature at night is relatively low, making photosynthesis and the accumulation of materials more efficient, which enhances bulb enlargement and root growth (Kim et al., 2000). The physiological and pathological degradation of Lilium seed bulbs can be reduced through a tissue culture technique. The research about virus-free health stock production is generalized. Research about Lilium (Choi, 1992; Goo et al., 2004; Kim et al., 1996; Park et al., 1997; Shin et al., 2002) has been carried out for virus-free plant production and became practically implemented. For the tissue culture of Lilium, a tissue scale is the most widely used explant. For mass multiplication from disease-free stocks of next generation tissue cultures, a multiplication method using a scale of Lilium is being widely used. However, it has been reported that seedling plants generated via callus induction from Lilium scales have a possibility of mutation (Kim and De Hertogh, 1997). Research about progeny bulb enlargement after a tissue culture has been conducted, testing bulblet formation capability based on temperature and scale attachment positioning (Park, 1992) and on the effect of scaling timing and the size of cut scales. Other research includes testing the effect of low temperature treatment of the mother bulbs on the number of bulblets, the weight of the bulblets, and bulblet diameter (Suh and Lee, 1995). Experiments on rot prevention in bulbs and the enlargement efficiency of bulblets (Goo, 2007; Park et al., 1997) were also performed. In spite of the availability of this various research, cumulative research about the environment for bulblet enlargement after propagation of lilies using scales is scarce. Therefore, a systematic production technique for bulb enlargement has not been generalized yet. In addition, there is a lack of research about the bulb formation capability obtained through propagation via scales. Also, various seed bulb standards and size qualifications for the marketing and export of lilies are lacking. Recently, the necessity of self-sufficiency for lily seed bulbs in Korea is on the rise. Lily production farms have tried to produce healthy seed bulbs; therefore, research about healthy bulb production is required. This study was conducted to investigate the production efficiency of seed bulbs oriented from scale tissue cultures to produce export-grade bulbs.

\section{Materials and Methods}

This study was conducted inside a rain-sheltered greenhouse in the highlands of Daegiri (altitude $780 \mathrm{~m}$, Wangsanmyeon, Gangneung City, Gangwon-do) where an experimental farm at Gangneung-Wonju National University is located. The seed bulbs used for the study were small bulblets of the three cultivars 'Casa Blanca', 'Siberia', and 'Sorbonne', which produced Oriental lilies. The lilies were produced from tissue culture in the Gangwon-do Agricultural Research \& Extension Services in 2006 and bulb enlargement was carried out over two years until October, 2007. Scaling was conducted using large bulbs of $16-18 \mathrm{~cm}$, and the scale bulblets were again enlarged for one year, from May until October, 2008. Finally, second-generation scale bulblets were obtained and classified based on their sizes as follows: less than $6 \mathrm{~cm}, 6-9 \mathrm{~cm}, 9-10 \mathrm{~cm}, 10-12 \mathrm{~cm}$, and 12-14 cm (Fig. 1). They were then planted on May 6, 2009. Experimental plots were arranged as a single planting. Since bulbs less than $6 \mathrm{~cm}$ and between 6-9 $\mathrm{cm}$ have less vitality, these were planted in the seedbed with peat moss, vermiculite, and rice husks at a ratio of 4:1:5. Fertilizer was categorized into initial, interim, and post. The various fertilizers were applied in time, and the EC of liquid fertilizer was adjusted to $0.5 \mathrm{dS} \cdot \mathrm{m}^{-1}$. The bulbs of bulb circumference (BC) $9-10 \mathrm{~cm}, 10-12 \mathrm{~cm}$, and $12-14 \mathrm{~cm}$ were planted in the soil. $600 \mathrm{~kg}$ of pre-planting fertilizer of oilcake per 10 $\mathrm{a}$ and $30 \mathrm{~kg}$ of horticultural compound fertilizer (14-12-12) were sprayed according to the calculated area. Bulbs were planted after plowing the soil, and three packets/ton of liquid fertilizer were applied during bulb growth for seven days using drip method and irrigation for fertigation. For weed control, the herbicide 'PARTNER' was sprayed once just after planting, and for the prevention of diseases and pests, a pesticide for aphids to prevent viruses and pesticides for leaf blight and phytophthora blight were mixed and sprayed from time to time. Bulbs were planted apart at a distance of $5 \times 2 \mathrm{~cm}$ for the bulblets of BC less than 6

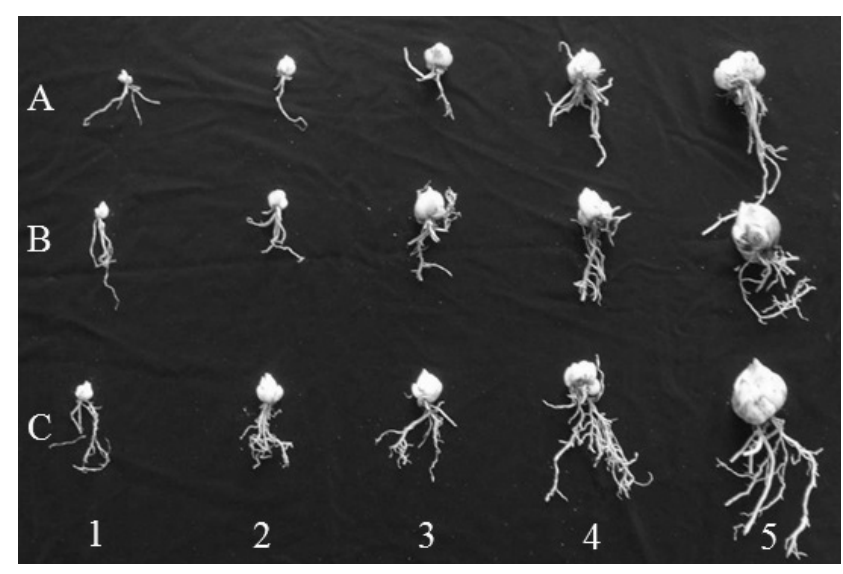

Fig. 1. Status of seed bulbs of Lilium Oriental hybrids 'Sorbonne' (A), 'Siberia' (B), and 'Casa Blanca' (C) used in this experiment at planting time in 2009. 1, bulbs under $6 \mathrm{~cm}$; 2 , bulbs $6-9 \mathrm{~cm} ; 3$, bulbs $9-10 \mathrm{~cm}$; 4 , bulbs $10-12 \mathrm{~cm}$; bulbs $12-14 \mathrm{~cm}$. 
$\mathrm{cm}, 7 \times 3 \mathrm{~cm}$ for the bulblets of $\mathrm{BC} 6-9 \mathrm{~cm}, 10 \times 3 \mathrm{~cm}$ for the bulblets of $\mathrm{BC} 9-10 \mathrm{~cm}, 18 \times 8 \mathrm{~cm}$ for the bulblets of $\mathrm{BC} 12-14 \mathrm{~cm}$, and $20 \times 12 \mathrm{~cm}$ for the bulblets of $\mathrm{BC}$ $10-14 \mathrm{~cm}$. Plant growth was determined based on the total height, number of leaves, leaf length, leaf width, chlorophyll contents, and the number of flowers observed at two-week intervals. The number of fallen leaves was determined as the average number of fallen leaves per week by arbitrarily selecting 15 stocks at each time of growth investigation. The ratios of virus-infected plants as well as botrytis-infected plants were marked as diseased plants per 300 plants. They were examined using only the naked eye. Chlorophyll content was measured from 5-6 leaves from the upper side of the stock with a chlorophyll analyzer (SPAD chlorophyll analyzer, Minolta, Osaka, Japan) and the results were expressed using the SPAD unit. The final harvest was done on October 10th, 2009, and 15 bulbs from each experimental plot were selected to measure bulblet diameter, bulblet height, bulblet weight, root number, and root length to compare the quality of harvested bulblets. When harvesting seed bulbs, 1,500 bulbs from each experimental plot were collected, washed, and graded. The bulbs which had some errors were sorted by the naked eye to determine seed bulb size.

Experimental results were analyzed by ANOVA using SAS system (SAS Institute Inc., Cary, NC 27513, USA) and a significance test was carried out using Duncan's multiple range test (DMRT) at $p \leq 0.05$ for each treatment.

\section{Results and Discussion}

The required dates for the appearance of small buds and flower buds for seed production of the Lilium cultivars 'Sorbonne' and 'Siberia', which are most widely cultivated domestically, and 'Casa Blanca', which is mostly exported to Japan, are presented in Table 1. The general growth and florescence earliness of commercially available Lilium cultivars are known to be in the order of 'Sorbonne' > 'Siberia' > 'Casa Blanca', but all three cultivars took 7-8 days for shoot emergence from the ground. As far as the shoot emergence date, small bulblets of bulb circumference (BC) less than $6 \mathrm{~cm}$ in all three cultivars took 8 days, 'Sorbonnne' of BC 12-14 cm took 6 days, and other bulbs took 7-8 days from all three cultivars, regardless of bulb size. The reason why shoot emergence from the small bulbs was relatively late compared to larger bulbs might be due to low vitality since the accumulation of nutrients is lower in small bulbs. From all the cultivars in all treatment plots, more than $93 \%$ of shoot appearance rate was observed, particularly from bulbs of BC larger than 6-9 $\mathrm{cm}$. The overall shoot appearance rate was more than $95 \%$. This might be due to high growth vitality in the proposed bulbs in this study as their physiological degeneration was lower since these were upper-stage bulbs after tissue cultures. However, flower buds were not formed from the bulbs of $\mathrm{BC}$ less than $6 \mathrm{~cm}$ in all three cultivars. Considering the growth amount, phase change of floral differentiation, and vitality of Lilium seed bulbs, the phase change to reproductive growth might be difficult due to a lack of nutritional growth in small bulbs. By observing flower bud generation from seed bulbs of $\mathrm{BC} 6-9 \mathrm{~cm}$ from the cultivars 'Sorbonne' and 'Siberia', it was judged that the critical boundary of phase change in these cultivars was with bulbs of BC 6-9 cm. It took 60 days for flower bud appearance, regardless of the cultivar type and seed bulb size, but it took 65 days in seed bulbs of BC 6-9 $\mathrm{cm}$ in 'Sorbonne'. This may also be due to a lack of accumulated nutrients in the seed bulb due to small bulb size, causing low growth vitality and delayed floral initiation. The number of flower buds increased as the size of the bulb increased, regardless of which type of cultivar the bud was. However, though the number of flower buds per set was 2.9 and 2.8 from the largest $\mathrm{BC}$ of 12-14 $\mathrm{cm}$ in 'Sorbonne' and 'Siberia', they were not qualified for export, but they were suitable for cut-flower production in the domestic market.

Table 1. Effects of bulblets size on shoot emergence and flowering in Lilium Oriental hybrids planted on highlands on early May, 2009.

\begin{tabular}{|c|c|c|c|c|}
\hline \multirow{2}{*}{$\begin{array}{l}\text { Seed bulb } \\
\text { size }(\mathrm{cm})\end{array}$} & \multicolumn{2}{|c|}{ Shoot emergence } & \multicolumn{2}{|c|}{ Visible flower bud } \\
\hline & $\begin{array}{c}\text { Days } \\
\text { Required }\end{array}$ & $\begin{array}{c}\text { Rate } \\
(\%)\end{array}$ & Days required & Number \\
\hline & \multicolumn{4}{|c|}{ 'Sorbonne' } \\
\hline$\leq 6$ & $8 a^{z}$ & 94.3 & - & - \\
\hline $6-9$ & 7 a & 95.6 & $65 a$ & $0.2 \mathrm{~d}$ \\
\hline $9-10$ & 7 a & 97.0 & $60 \mathrm{a}$ & $1.0 \mathrm{c}$ \\
\hline $10-12$ & 7 a & 97.6 & $60 \mathrm{a}$ & $1.8 \mathrm{~b}$ \\
\hline \multirow[t]{2}{*}{$12-14$} & 6 a & 98.3 & $60 \mathrm{a}$ & $2.9 \mathrm{a}$ \\
\hline & \multicolumn{4}{|c|}{ 'Siberia' } \\
\hline$\leq 6$ & $8 a$ & 93.7 & - & - \\
\hline $6-9$ & $8 a$ & 95.3 & $60 a$ & $0.1 \mathrm{c}$ \\
\hline $9-10$ & $7 \mathrm{a}$ & 95.9 & $60 a$ & $1.0 \mathrm{bc}$ \\
\hline $10-12$ & $7 \mathrm{a}$ & 96.3 & $60 \mathrm{a}$ & $1.9 a b$ \\
\hline \multirow[t]{2}{*}{$12-14$} & $7 \mathrm{a}$ & 97.6 & $60 \mathrm{a}$ & $2.8 \mathrm{a}$ \\
\hline & \multicolumn{4}{|c|}{ 'Casa Blanca' } \\
\hline$\leq 6$ & $8 a$ & 93.3 & - & - \\
\hline $6-9$ & 7 a & 94.7 & - & - \\
\hline $9-10$ & $8 a$ & 96.6 & $60 a$ & $0.1 \mathrm{~b}$ \\
\hline $10-12$ & 7 a & 94.6 & $60 a$ & $1.1 \mathrm{ab}$ \\
\hline $12-14$ & 7 a & 96.3 & $60 \mathrm{a}$ & $2.0 \mathrm{a}$ \\
\hline
\end{tabular}

${ }^{\mathrm{z}}$ Mean separation within columns by Duncan's multiple range test, $p \leq 0.05$. 
'Casa Blanca' had 2.0 flower buds amongst bulbs of the same size, and also had thinner, softer stems, so they were not qualified as cut-flowers.

The differences in growth characteristics and size from each cultivar are shown in Table 2. The growth of lilies above ground quantitatively increased as seed bulb size was increased in all three cultivars in terms of plant height, number of leaves, leaf length, and leaf width. These results also might be an evidence of the nutrition in the mother bulb, which is directly connected to growth vitality. As seed bulb size increased, plant height also increased during the growth phase. In all three cultivars, 'Sorbonne', 'Siberia', and 'Casa Blanca', abrupt plant height growths were observed from the bulblets of BC 9-10 cm and compared to smaller bulblets. That is, plant height increased nearly $30 \mathrm{~cm}$ from the bulb of BC $6 \mathrm{~cm}$ as well as BC $6-9 \mathrm{~cm}$ in 'Sorbonne', while plant height from bulblets of $\mathrm{BC}$ more than $9-10 \mathrm{~cm}$ was $64 \mathrm{~cm}$ in all the bulbs; that is more than twice than in other bulb size groups. Leaf number and leaf width also grew rapidly from the bulbs of BC $9-10 \mathrm{~cm}$, and other cultivars showed similar tendencies. The growth vitality of the seed bulbs improved largely at around BC $10 \mathrm{~cm}$, and phase change might be induced, increasing vitality. The largest plant height was also observed from the bulblets of BC $12-14 \mathrm{~cm}$. The increase in leaf number was 13 from bulblets of BC less than $6-9 \mathrm{~cm}$ in all three cultivars, but leaf number was abruptly increased by 5 , totaling 18 from bulbs of BC 9-10 cm. The leaf surface area determines the amount of photosynthesis, and excessive growth causes negative effects such as restricted photosynthesis due to poor lighting and ventilation and increases in the occurrence of disease by microorganisms. With increases in seed bulb size, leaf size increased, but the plants did not appear luxuriantly grown. Leaf length and width were used to decide the difference in leaf size from different cultivars. Characteristically, 'Sorbonne' has small leaves, 'Siberia' has relatively narrow leaves, and 'Casa Blanca' has long leaves. As for the growth of leaves and stems, while the difference in bulb size was absolute, the difference in chlorophyll content was meager. The vitality of the lily seed bulbs can be recognized by appearance, considering plant height, leaf size, gloss, and fallen leaves. Summer cultivation in low temperatures during July and August in the lowlands will seriously limit not only the growth of shooting parts, but also bulb enlargement due to dormancy and leaf burn.

However, in the highlands, where the mean temperature is between $19-21^{\circ} \mathrm{C}$ during July and August, the summers are cool and humid, and dormancy of plants can be avoided, especially because aphids which are insect vectors for viruses are fewer, so the infection rate is low. It is being reported as the optimum place for seed bulb production.

Table 2. Effects of bulblets size on growth characteristics in Lilium Oriental hybrids planted on highlands on early May, 2009.

\begin{tabular}{|c|c|c|c|c|c|}
\hline $\begin{array}{l}\text { Seed bulb size } \\
(\mathrm{cm})\end{array}$ & $\begin{array}{l}\text { Stem length } \\
(\mathrm{cm})\end{array}$ & $\begin{array}{l}\text { No. of } \\
\text { leaves }\end{array}$ & $\begin{array}{l}\text { Leaf length } \\
\qquad(\mathrm{cm})\end{array}$ & $\begin{array}{l}\text { Leaf width } \\
\qquad(\mathrm{cm})\end{array}$ & $\begin{array}{c}\text { Chlorophyll contents } \\
\text { (SPAD unit) }\end{array}$ \\
\hline & & & 'Sorbonne' & & \\
\hline$\leq 6$ & $29.4 c^{z}$ & $13.7 \mathrm{c}$ & $8.6 \mathrm{~b}$ & $3.3 a b$ & $35.1 \mathrm{a}$ \\
\hline $6-9$ & $32.6 \mathrm{c}$ & $13.6 \mathrm{c}$ & $7.8 \mathrm{~b}$ & $3.1 \mathrm{~b}$ & $32.8 \mathrm{a}$ \\
\hline $9-10$ & $64.0 \mathrm{~b}$ & $18.1 \mathrm{bc}$ & $9.7 \mathrm{ab}$ & $3.7 \mathrm{ab}$ & $34.6 \mathrm{a}$ \\
\hline $10-12$ & $70.8 a b$ & $25.5 a b$ & $10.3 a b$ & $3.8 a b$ & $37.0 \mathrm{a}$ \\
\hline \multirow[t]{2}{*}{$12-14$} & 76.2 a & $29.3 a$ & $11.4 a$ & $4.4 \mathrm{a}$ & $40.2 \mathrm{a}$ \\
\hline & & & 'Siberia' & & \\
\hline$\leq 6$ & $28.4 \mathrm{c}$ & $15.7 \mathrm{ab}$ & $9.6 \mathrm{~b}$ & $3.7 \mathrm{~b}$ & $32.7 \mathrm{a}$ \\
\hline $6-9$ & $28.0 \mathrm{c}$ & $15.2 b$ & $9.6 \mathrm{~b}$ & $3.5 \mathrm{~b}$ & $36.5 \mathrm{a}$ \\
\hline $9-10$ & $43.8 \mathrm{~b}$ & $17.6 a b$ & $12.6 \mathrm{a}$ & $4.3 a b$ & $32.7 \mathrm{a}$ \\
\hline $10-12$ & $57.5 b$ & $26.6 \mathrm{ab}$ & $14.1 \mathrm{a}$ & $5.4 \mathrm{a}$ & $36.6 \mathrm{a}$ \\
\hline \multirow[t]{2}{*}{$12-14$} & $71.6 \mathrm{a}$ & $27.1 \mathrm{a}$ & $14.9 \mathrm{a}$ & $5.3 \mathrm{a}$ & $39.4 \mathrm{a}$ \\
\hline & & & 'Casa Blanca' & & \\
\hline$\leq 6$ & $23.1 \mathrm{c}$ & $11.5 \mathrm{a}$ & $8.4 \mathrm{c}$ & $3.2 \mathrm{c}$ & $35.0 \mathrm{a}$ \\
\hline $6-9$ & $31.8 \mathrm{c}$ & $13.3 a$ & $15.1 \mathrm{a}$ & $3.4 \mathrm{c}$ & 36.2 a \\
\hline $9-10$ & $50.1 \mathrm{~b}$ & $18.1 \mathrm{a}$ & $11.5 b$ & $3.9 \mathrm{bc}$ & $32.8 \mathrm{a}$ \\
\hline $10-12$ & $56.0 \mathrm{~b}$ & $23.3 \mathrm{a}$ & $14.8 \mathrm{a}$ & $4.4 \mathrm{ab}$ & $42.2 \mathrm{a}$ \\
\hline $12-14$ & $73.1 \mathrm{a}$ & $27.6 \mathrm{a}$ & $15.3 \mathrm{a}$ & $4.9 \mathrm{a}$ & $36.8 \mathrm{a}$ \\
\hline
\end{tabular}

${ }^{z}$ Mean separation within columns by Duncan's multiple range test, $p \leq 0.05$. 
For the lilies which are low-temperature crops and vegetativepropagated crops, it could be the best production site for seed bulbs. During the experimental period, especially during the hot summers in July and August, high-temperature injuries such as halted growth or leaf burn were never found. The disease infection rate in the lilies was very low (Table 3). The reason why the virus infection rate in the experimental plot was low might be due to low temperatures and humid environmental conditions, which are unfavorable for aphids. Also, the bulb used was from the upper class progeny of tissue culture which reached the first scale propagation stage. Meanwhile, with decreases in seed bulb size from all three cultivars, the disease infection rate was high. This might be because there were some bulbs whose growth was slower during cultivation because they were already infected during the previous year rather than infected in the field in the current year. Particularly, infected plants were not found from bulbs of BC 10-12 cm in 'Sorbonne'. Only one plant was found infected from bulb circumference $12-14 \mathrm{~cm}$. Therefore, the disease infection rate was just $0.2 \%$, whereas, from bulbs of $\mathrm{BC} 10-12 \mathrm{~cm}$ as well as BC 12-14 cm in 'Casa Blanca', both the disease infection rates were $0.2 \%$. As far as the cultivars are concerned, the disease infection rate between 'Sorbonne' and 'Casa Blanca' was similar, but the disease infection rate was a little bit higher in 'Siberia', which suggests more research is required about this phenomena because this cultivar may be little bit vulnerable to the virus. The occurrence of Botrytis was found to be similar in 'Sorbonne' and 'Siberia', but it was not serious enough to hamper the product value, whereas 'Casa Blanca' showed somewhat advanced disease symptoms. Leaves falling by drying and falling of lower leaves in the experimental farm might be due to physiological factors rather than pathological ones. That means, since it was the summer cultivation period in the highlands, there were many temperature fluctuations, nutritional excess and shortage, moisture changes in the soil, and air ventilation differences. These factors might have directly affected the lower leaves falling. Leaf falling was especially high in 'Casa Blanca', whose stem and leaves are luxuriant and the cultivation period was long, thus showing an inferior adaptability towards environmental changes as compared with those of 'Siberia' and 'Sorbonne'.

The comparison results of the produced seed bulbs quality in this study are presented in Table 4 . It is natural that the nutritional substance of seed bulbs is reflected on the bulb.

Table 3. Effects of bulblets size on disease infection and leaf-fall in Lilium Oriental hybrids planted on highlands on early May, 2009.

\begin{tabular}{|c|c|c|c|c|c|}
\hline \multirow{3}{*}{ Seed bulb size $(\mathrm{cm})$} & \multicolumn{4}{|c|}{ Disease infection } & \multirow{3}{*}{$\begin{array}{l}\text { No. of fallen leaves } \\
\text { (c) }\end{array}$} \\
\hline & \multicolumn{2}{|c|}{ Virus disease } & \multicolumn{2}{|c|}{ Botrytis blight } & \\
\hline & Number $^{z}$ & Rate $(\%)$ & Number $^{y}$ & Rate $(\%)$ & \\
\hline & & & 'Sorbonne & & \\
\hline$\leq 6$ & 5 & 0.8 & 2 & 0.3 & 0.1 \\
\hline $6-9$ & 5 & 0.8 & - & - & 0.2 \\
\hline $9-10$ & 3 & 0.5 & 1 & 0.2 & - \\
\hline $10-12$ & - & - & 2 & 0.3 & - \\
\hline \multirow[t]{2}{*}{$12-14$} & 1 & 0.2 & - & - & 0.2 \\
\hline & & & 'Siberia' & & \\
\hline$\leq 6$ & 6 & 1.0 & 2 & 0.3 & 0.2 \\
\hline $6-9$ & 3 & 0.5 & 2 & 0.3 & - \\
\hline $9-10$ & 5 & 0.8 & - & - & 0.1 \\
\hline $10-12$ & 3 & 0.5 & 2 & 0.3 & 0.3 \\
\hline \multirow[t]{2}{*}{$12-14$} & 2 & 0.3 & 1 & 0.2 & 0.2 \\
\hline & \multicolumn{5}{|c|}{ 'Casa Blanca' } \\
\hline$\leq 6$ & 5 & 0.8 & 3 & 0.5 & - \\
\hline $6-9$ & 5 & 0.8 & 2 & 0.3 & 0.2 \\
\hline $9-10$ & 4 & 0.7 & 1 & 0.2 & 0.2 \\
\hline $10-12$ & 1 & 0.2 & 2 & 0.3 & 0.3 \\
\hline $12-14$ & 1 & 0.2 & 1 & 0.2 & 0.1 \\
\hline
\end{tabular}

${ }^{\mathrm{z}, \mathrm{y}}$ Total number of diseased plants (per/600 plants).

${ }^{x}$ Average number of fallen leaves per plant. 
Therefore, with increases in the size of the mother bulb, large seed bulbs will be produced, yet bulb enlargement efficiency was different even among cultivars in the order of 'Sorbonne' $>$ 'Casa Blanca' $>$ 'Siberia'. Particularly from small bulbs of BC less than $6 \mathrm{~cm}$ in 'Sorbonne', a bulb weighing more than $29.9 \mathrm{~g}$ was produced, and a higher rate of good bulbs was shown from other sized bulbs also as compared with other cultivars. Bulblet height and bulblet diameter showed relatively higher values with increases in bulb weight. The number of scales compared to bulblet weight was high in all the bublet sizes with somewhat higher scale numbers in 'Casa Blanca'.

In addition, development in the root number and root length were better with increases in the bulblet sizes but with no significant difference, and the comparison between cultivars showed superior root growth in 'Casa Blanca' compared to 'Sorbonne' and 'Siberia'. Overall bulb growth and enlargement characteristics in 'Casa Blanca' showed a weak tendency from small bulbs of BC less than $6 \mathrm{~cm}$ and $6-9 \mathrm{~cm}$, but the vitality became remarkably increased in bulblets of $\mathrm{BC}$ from larger than $9-10 \mathrm{~cm}$, proving its high efficiency in seed bulblet production.

Harvesting seed bulbs of flowering potential produced by sawing standard bulbs in each cultivar yielded high results, in the order of 'Sorbonne' > 'Siberia' > 'Casa Blanca', with 'Sorbonne' having a smaller number of bulbs smaller than BC 12-14 cm compared with other cultivars (Table 5). 'Sorbonne' produced 255 (17\%) bulbs of BC $14-16 \mathrm{~cm}$, $105(7 \%)$ bulbs of $\mathrm{BC} 16-18 \mathrm{~cm}$, and $15(1 \%)$ remarkably large bulbs of $\mathrm{BC}$ larger than $18 \mathrm{~cm}$ even from smaller bulblets of $\mathrm{BC}$ less than $6 \mathrm{~cm}$, totaling 1,500 planted seed bulbs. The production rate of bulbs of $\mathrm{BC} 14-16 \mathrm{~cm}$ that can be used for cut-flower production was $25 \%$ even if smaller bulblets of BC less than $6 \mathrm{~cm}$ were planted. When bulbs of BC larger than $10 \mathrm{~cm}$ were planted, more than $99 \%$ of the bulbs had the potential to be used in cut-flower production. In 'Siberia', seed bulb production of BC less than $12-14 \mathrm{~cm}$ was large (81\%) from the experimental plot, grown from bulblets of $\mathrm{BC}$ less than $6 \mathrm{~cm}$. The rate of seed bulb production of $\mathrm{BC}$ below $14-16 \mathrm{~cm}$ that can produce cut-flowers was $75 \%$ from the plot with $\mathrm{BC} 6-9$ $\mathrm{cm}, 15 \%$ rate for seed bulbs of $\mathrm{BC} 14-16 \mathrm{~cm}, 6 \%$ rate for seed bulbs of BC $16-18 \mathrm{~cm}$, and just $4 \%$ rate for seed bulbs of $\mathrm{BC}$ larger than $18 \mathrm{~cm}$.

The cultivar with the least bulb enlargement was 'Casa Blanca', where bulb production of BC 14-16 cm for cut-flower production was literally zero from small bulbs of BC less than $6 \mathrm{~cm}$. Even from smaller bulbs of BC $6-9 \mathrm{~cm}$, the noncompetitive bulbs for export with bulbs of BC 12-14 $\mathrm{cm}$ reached $79 \%$, and there was no bulb larger than $\mathrm{BC}$

Table 4. Effects of bulblets size on underground parts in Lilium Oriental hybrids planted on highlands on early May, 2009.

\begin{tabular}{|c|c|c|c|c|c|c|c|}
\hline \multirow{2}{*}{$\begin{array}{l}\text { Seed bulb size } \\
(\mathrm{cm})\end{array}$} & \multicolumn{5}{|c|}{ Bulb } & \multicolumn{2}{|c|}{ Root } \\
\hline & $\begin{array}{l}\text { Weight } \\
\text { (g) }\end{array}$ & $\begin{array}{l}\text { Height } \\
(\mathrm{cm})\end{array}$ & $\begin{array}{l}\text { Diameter } \\
(\mathrm{cm})\end{array}$ & $\begin{array}{c}\text { Circumference } \\
(\mathrm{cm})\end{array}$ & $\begin{array}{c}\text { Scale } \\
\text { number }\end{array}$ & Number & $\begin{array}{l}\text { Length } \\
(\mathrm{cm})\end{array}$ \\
\hline & \multicolumn{7}{|c|}{ 'Sorbonne' } \\
\hline$\leq 6$ & $29.9 c^{z}$ & $3.5 \mathrm{~b}$ & $3.0 \mathrm{c}$ & $9.4 \mathrm{c}$ & $13.8 \mathrm{a}$ & $4.2 \mathrm{~b}$ & $9.0 \mathrm{c}$ \\
\hline $6-9$ & $40.0 \mathrm{c}$ & $4.4 a b$ & $4.0 \mathrm{bc}$ & $12.6 \mathrm{bc}$ & $14.9 \mathrm{a}$ & $6.6 \mathrm{ab}$ & $11.6 \mathrm{bc}$ \\
\hline $9-10$ & $64.8 \mathrm{~b}$ & $4.9 a b$ & $5.2 a b$ & $16.3 a b$ & $22.6 \mathrm{a}$ & $5.7 \mathrm{ab}$ & $13.2 \mathrm{ab}$ \\
\hline $10-12$ & $73.9 \mathrm{~b}$ & 5.6 a & $5.5 \mathrm{ab}$ & $17.3 a b$ & $24.5 \mathrm{a}$ & $7.6 \mathrm{ab}$ & $10.4 \mathrm{bc}$ \\
\hline $12-14$ & \multicolumn{7}{|c|}{ 'Siberia' } \\
\hline$\leq 6$ & $27.3 \mathrm{c}$ & $3.2 \mathrm{~b}$ & $2.9 \mathrm{c}$ & $9.1 \mathrm{c}$ & $18.2 \mathrm{a}$ & $4.0 \mathrm{~b}$ & $8.3 \mathrm{a}$ \\
\hline $6-9$ & $34.8 \mathrm{bc}$ & $3.9 a b$ & $3.8 \mathrm{bc}$ & $11.9 \mathrm{bc}$ & $20.6 a$ & $6.1 \mathrm{~b}$ & $14.2 \mathrm{a}$ \\
\hline $9-10$ & $43.2 \mathrm{~b}$ & $4.3 \mathrm{ab}$ & $4.3 \mathrm{abc}$ & $13.5 \mathrm{bc}$ & $22.4 \mathrm{a}$ & $5.7 \mathrm{~b}$ & $13.5 \mathrm{a}$ \\
\hline $10-12$ & $67.4 \mathrm{a}$ & $5.0 \mathrm{ab}$ & $5.1 \mathrm{ab}$ & $16.0 \mathrm{ab}$ & $24.5 \mathrm{a}$ & $6.2 \mathrm{~b}$ & $12.0 \mathrm{a}$ \\
\hline \multirow[t]{2}{*}{$12-14$} & 78.2 a & 5.9 a & $6.1 \mathrm{a}$ & 19.2 a & $26.8 \mathrm{a}$ & $9.7 \mathrm{a}$ & $14.3 \mathrm{a}$ \\
\hline & \multicolumn{7}{|c|}{ 'Casa Blanca' } \\
\hline$\leq 6$ & $19.7 \mathrm{~d}$ & $3.0 \mathrm{~b}$ & $3.1 \mathrm{~b}$ & $9.7 \mathrm{c}$ & $20.0 \mathrm{a}$ & $6.7 \mathrm{~b}$ & $22.8 \mathrm{a}$ \\
\hline $6-9$ & $30.0 \mathrm{c}$ & $3.9 a b$ & $3.8 a b$ & $11.9 \mathrm{c}$ & $21.2 \mathrm{a}$ & $9.0 \mathrm{ab}$ & $20.1 \mathrm{a}$ \\
\hline $9-10$ & $49.7 b$ & $4.9 \mathrm{ab}$ & $4.4 \mathrm{ab}$ & $13.8 \mathrm{bc}$ & $22.4 \mathrm{a}$ & $7.3 \mathrm{ab}$ & $25.1 \mathrm{a}$ \\
\hline $10-12$ & $73.3 \mathrm{a}$ & $4.8 \mathrm{ab}$ & $5.4 a b$ & $17.0 \mathrm{ab}$ & $24.4 \mathrm{a}$ & $8.7 \mathrm{ab}$ & $23.4 \mathrm{a}$ \\
\hline $12-14$ & $80.8 \mathrm{a}$ & $5.1 \mathrm{a}$ & $6.2 \mathrm{a}$ & $19.5 \mathrm{a}$ & $30.0 \mathrm{a}$ & $10.6 \mathrm{a}$ & $26.5 \mathrm{a}$ \\
\hline
\end{tabular}

${ }^{\mathrm{z}}$ Mean separation within columns by Duncan's multiple range test, $P \leq 0.05$. 
Table 5. Effects of bulblets size on bulb enlargement after harvest in Lilium Oriental hybrids planted on highlands on early May, 2009.

\begin{tabular}{|c|c|c|c|c|c|c|c|c|c|c|}
\hline \multirow{3}{*}{$\begin{array}{l}\text { Seed bulb size } \\
(\mathrm{cm})\end{array}$} & \multicolumn{10}{|c|}{ Harvested bulb circumference $(\mathrm{cm})$} \\
\hline & \multicolumn{2}{|c|}{$\leq 12$} & \multicolumn{2}{|c|}{$12-14$} & \multicolumn{2}{|c|}{$14-16$} & \multicolumn{2}{|c|}{$16-18$} & \multicolumn{2}{|c|}{$\geq 18$} \\
\hline & No. & $\%$ & No. & $\%$ & No. & $\%$ & No. & $\%$ & No. & $\%$ \\
\hline & \multicolumn{10}{|c|}{ 'Sorbonne' } \\
\hline$\leq 6$ & 855 & 57 & 270 & 18 & 255 & 17 & 105 & 7 & 15 & 1 \\
\hline $6-9$ & 405 & 27 & 570 & 38 & 300 & 20 & 180 & 12 & 45 & 3 \\
\hline $9-10$ & 15 & 1 & 150 & 10 & 450 & 30 & 585 & 39 & 300 & 20 \\
\hline $10-12$ & - & - & 15 & 1 & 255 & 17 & 630 & 42 & 600 & 40 \\
\hline \multirow[t]{2}{*}{$12-14$} & - & - & - & - & 15 & 1 & 390 & 26 & 1,095 & 73 \\
\hline & \multicolumn{10}{|c|}{ 'Siberia' } \\
\hline$\leq 6$ & 915 & 61 & 300 & 20 & 165 & 11 & 75 & 5 & 45 & 3 \\
\hline $6-9$ & 795 & 53 & 330 & 22 & 225 & 15 & 90 & 6 & 60 & 4 \\
\hline $9-10$ & 315 & 21 & 525 & 35 & 375 & 25 & 195 & 13 & 90 & 6 \\
\hline $10-12$ & 15 & 1 & 195 & 13 & 285 & 19 & 510 & 34 & 495 & 33 \\
\hline \multirow[t]{2}{*}{$12-14$} & - & - & 15 & 1 & 150 & 10 & 645 & 43 & 690 & 46 \\
\hline & \multicolumn{10}{|c|}{ 'Casa Blanca' } \\
\hline$\leq 6$ & 1,425 & 95 & 75 & 5 & - & - & - & - & - & - \\
\hline $6-9$ & 885 & 59 & 300 & 20 & 225 & 15 & 90 & 6 & - & - \\
\hline $9-10$ & 315 & 21 & 450 & 30 & 315 & 21 & 225 & 15 & 195 & 13 \\
\hline $10-12$ & - & - & 105 & 7 & 150 & 10 & 645 & 43 & 600 & 40 \\
\hline $12-14$ & - & - & - & - & 75 & 5 & 480 & 32 & 945 & 63 \\
\hline
\end{tabular}

$18 \mathrm{~cm}$. However, when bulbs of $\mathrm{BC} 12-14 \mathrm{~cm}$ were planted, production of more than $95 \%$ of standard bulbs of BC 16-18 cm was achieved. The seed production of bulbs of BC more than 14-16 cm that were cut-flower grade was $25 \%$ from the experimental plot with bulblets less than $\mathrm{BC}$ $6 \mathrm{~cm}, 35 \%$ in the plot with bulblets of BC $6-9 \mathrm{~cm}, 89 \%$ in the plot with bulblets of BC $9-10 \mathrm{~cm}, 99 \%$ in the plot with bulblets of BC $10-12 \mathrm{~cm}$, and $100 \%$ in the plot with bulblets of BC 12-14 cm for 'Sorbonne' cultivars. In 'Siberia' cultivars, the production rates were found as $19 \%$, $25 \%, 44 \%, 86 \%$, and 99\%, respectively. However, in 'Casa Blanca', seed bulb production of $14-16 \mathrm{~cm}$ was not possible with small bulbs of $\mathrm{BC}$ less than $6 \mathrm{~cm}$. Even when bulblets of BC 6-10 cm were planted, the cut-flower grade bulb production was below 50\% (Table 5). When bulbs of BC $10-12 \mathrm{~cm}$ were planted, the cut-flower grade bulb production rate was $93 \%$, whereas with bulbs of $\mathrm{BC} 12-14$ $\mathrm{cm}, 100 \%$ cut-flower grade bulb production could be achieved. For the production of export-grade cut-flowers, standard bulb production of seed bulbs of BC larger than $14-16 \mathrm{~cm}$ was required. This was confirmed during this study because seed bulbs of BC $9-10 \mathrm{~cm}$ were produced in $89 \%$ of 'Sorbonne' cultivars, $86 \%$ of 'Siberia' cultivars, and $93 \%$ of 'Casa Blanca' cultivars. Thus, bulbs of BC higher than said levels need to be planted. For the production of the best export-grade seed bulbs of $\mathrm{BC}$ more than $18 \mathrm{~cm}$, bulblets of $\mathrm{BC} 12-14 \mathrm{~cm}$ would be required in all three cultivars. Also, for the small bulblets of BC less than 6-9 $\mathrm{cm}$, if fertilizer composition were adjusted to make vegetative growth and reproductive growth as mooth process, cut-flower production for the domestic market is feasible.

\section{Literature Cited}

Choi, J.G. 1992. System establishment for producing virus-free lily stocks by high sensibility tissue blotting. RDA Res. Rpt. The Ministry of Science-Technology, Seoul, Korea.

Goo, D.H., B.W. Yea, and B.H. Han. 2004. In vitro propagation and enlargement of Lilium hansonii. Kor. J. Hort. Sci. Technol. 22:473-476.

Goo, D.H. 2007. Establishment of effective methods for scaling and bulblet enlargement of lily. Flower Res. J. 15:256-264.

Hong, S.J., H.K. Kim, and S.W. Park. 2001. Effect of mulching materials on growth and flowering of Oriental hybrids lilies in alpine area. J. Kor. Soc. Hort. Sci. 19:585-590.

Jeong, H. 2001. Development of mass production technology for lily seed bulb and its agricultural application. Kor Res. Inst. Biosci. Biotechnol. Res. Rpt. The Ministry of Agriculture, Gwacheon, Korea.

Kim, H.J., J.M. Kim, C.S. Kim, and H.G. Kim. 1998. System establishment for bulb production of Oriental hybrid lily: Method for tissue culture of bulblet. Jeonbuk Province Agr. 
Res. Ext. Serv. Expt. Res. Rpt. p. 478-483.

Kim, H.K. 1999. Studies on abilities of bulb enlargement in high land and low land for seed bulb production of Lilium Oriental hybrid. J. East Coastal Res. 10:1-13.

Kim, H.K., S.C. Lee, S.Y. Sun, and S.H. Jun. 2000. Effects of cultivation area and planting time on bulb growth and enlargement of Lilium Oriental hybrid in seed bulb production. J. East Coastal Res. 11:63-79.

Kim, J.Y., S.T. Choi, M.S. Roh, and T.S. Ko. 1996. Production and detection of virus-free lily plants by shoot tip culture and virazole treatment of bulbils. J. Kor. Soc. Hort. Sci. 37:64-69.

Kim, K.W. and A.A. De Hertogh. 1997. Tissue culture of ornamental flowering bulbs (geophytes). Hort. Rev. 18:87-169.

Ministry of Agriculture and Forestry (MAF). 2011. The status of floriculture cultivation in 2010. MAF, Gwacheon, Korea.
Park, N.B. 1992. Studies on scale propagation for bulblet formation in Oriental lily hybrids. J. Kor. Flower Res. Soc. 1:47-50.

Park, N.B., C.S. Kim, H.J. Kim, and S.G. Jin. 1997. Development of substitutional skill for seed bulb produce of bulbous flower to prevent the bulb import: System establishment for bulb production of Oriental hybrid lily. Jeonbuk Province Agr. Res. Ext. Serv. Expt. Res. Rpt. p. 377-388.

Shin, K.S., D. Chakrabarty, and K.Y. Paek. 2002. Sprouting rate, change of carbohydrate contents and related enzymes during the cold treatment of lily bulblets regenerated in vitro. Sci. Hort. 96:195-204.

Suh, J.K. and J.S. Lee. 1995. Propagation by bulb-scaling and leaf cutting of Lilium Asiatic hybrid. J. Kor. Soc. Hort. Sci. 36:248-254. 